Vol. 2, No. 2, 2015

\author{
N. Y. Podolchak \\ Doctor of Economics, Professor, \\ G. R. Kovalchuk, O. I. Savchyn \\ Assistant, \\ Lviv Polytechnic National University

\section{DEVELOPMENT METHODS OF CONFLICTS IDENTIFICATION AND EVALUATION}

\begin{abstract}
It has been elaborated the method for quantitative evaluation of level and structure of the interpersonal management conflicts that prevail over the other conflicts in the machine-building enterprises functioning. According to the reasons of appearance investigated interpersonal management conflicts were divided into the following types: informational, behavioral, structural, conflicts of relationships and values. The method was developed due to the usage of conjoint analysis that allows to evaluate simultaneously both the structure of the conflict and its level according to the priorities system, which has increased the credibility of gained results. Calculated values have shown that the prevailing conflicts in the structure of machine-building enterprises management conflict are informational ones that are related to poor information support of companies' administrators. The behavioral and relationship conflicts are also rather significant. They have different appearance nature and require special methods for their solution.

Dynamics of the environment, complexity of organization and communication structures, increase of the competition level, uncertainty in a number of market spheres, growth of the negative crisis outcomes, struggle between countries for markets and resources, active political confrontation especially in the developing countries are causing the general increase of the number of conflicts and conflicts levels. All the stated above factors of conflicts lie beyond the limits of enterprises influence on them, which is why they require the constant monitoring and appropriate adjustment on the part of the organization. However, it is not less important to consider the subjective component of conflict appearance - lack of desire to see the mutual advantage of cooperation, possibility to avoid conflicts with minimal losses, confidence in the accuracy of one's objectives, principles and convictions, asymmetry and monocentricity of corporate culture, managers indifference towards the occurrence of conflict situations, which leads to irreversibility of negative effects and significant losses caused by conflicts activity.

Hereby the task for enterprises managers is to identify the potential conflict situations actively, sometimes to provoke their appearance in order to resolve the management problems, to evaluate their
\end{abstract}

level, to influence their course and to try to receive functional results.

Key words: interpersonal management conflicts, machine-building enterprise, conflict identification, conflict evaluation.

Analysis of recent studies and publications. The problems of identification and quantitative evaluation of management conflicts in the enterprise functioning have been researched by both domestic and foreign scientists, including: A. J. Antsupov (2009), S. L. Boehm (1974), P. P. Gornostay (1997), S. Yerina (2002), H. Cornelius and C. Fair (1992), T. A. Polozova (2007), I. Sivchuk (2012), K. Smith (1993). All the methods of estimation process can be divided into usage of qualitative evaluation criteria and quantitative identification indicators and into determination of the conflicts level.

An interesting method of conflict identification that is called mapping was suggested by Australian scientists H. Cornelius and S. Fair (Cornelius and Fair, 1992: 250-268). The key point of this technique consists in the development of identifying map that contains the following elements: the parties of conflict management, their needs and concerns. According to the authors of this method such maps are very effective in preparation for ensuring negotiations and business contacts, negotiations that have no logical development, resources allocation, avoiding the tension inside the team and personnel risk (in particular staff turnover), implementation of innovations and changes etc.

S. I. Yerina has suggested diagnostic scale of management role conflicts. The approach designed by her makes it possible to identify and evaluate management conflict that arises in the work of lower level management (Yerina, 2002: P. 203-207).

Another method has been developed by Russian psychologist T. A. Polozova to study relationships between team members, in particular, to evaluate and identify interpersonal conflicts inside of certain administrative groups (Polozova, 


\section{N. Y. Podolchak, G. R. Kovalchuk, O. I. Savchyn}

2007). The method of A. Y. Antsupov "modular methods of interpersonal conflicts diagnosis" is similar to the previous one (Antsupov, 2009: 200-220). Except qualitative criteria I. I. Sivchuk has also proposed quantitative methods of conflicts identifying and measuring taking into consideration the corporate enterprise culture (Sivchuk, 2012].

Remaining parts of the problem. While evaluating the level of conflicts it is essential to identify the structure within the complex of all management conflicts. To do this, a certain system and dominant features of homogeneous management conflicts structure formation have to be chosen. From the standpoint of an effective conflict management system construction it is very important to identify the root causes of conflict appearance, which will give an opportunity to develop a set of measures aimed at avoiding or reducing the dysfunctional effects of conflicts activity. Therefore, it is rather important to choose the criterion that structures conflicts according to their reasons and factors of appearance. Moreover, it is essential to elaborate specific quantitative indicators of conflicts structure detection and conflicts levels.

The purpose of the study. The research purpose is to develop the method of quantitative identification and evaluation of the interpersonal management conflicts structure and levels in the machine-building enterprises by using modern economically statistic tools.

Summary of the basic material. Before the development of conflicts identification and evaluation methods the structure of the conflicts should be determined. Thus, in relation to appearance reasons Lincoln suggests dividing all kinds of conflicts into informational, behavioral, structural, conflicts of relations and values.

To identify and evaluate conflicts it was proposed to apply the method of conjoint analysis. Sequence of conjoint analysis usage is shown in Figure 1.

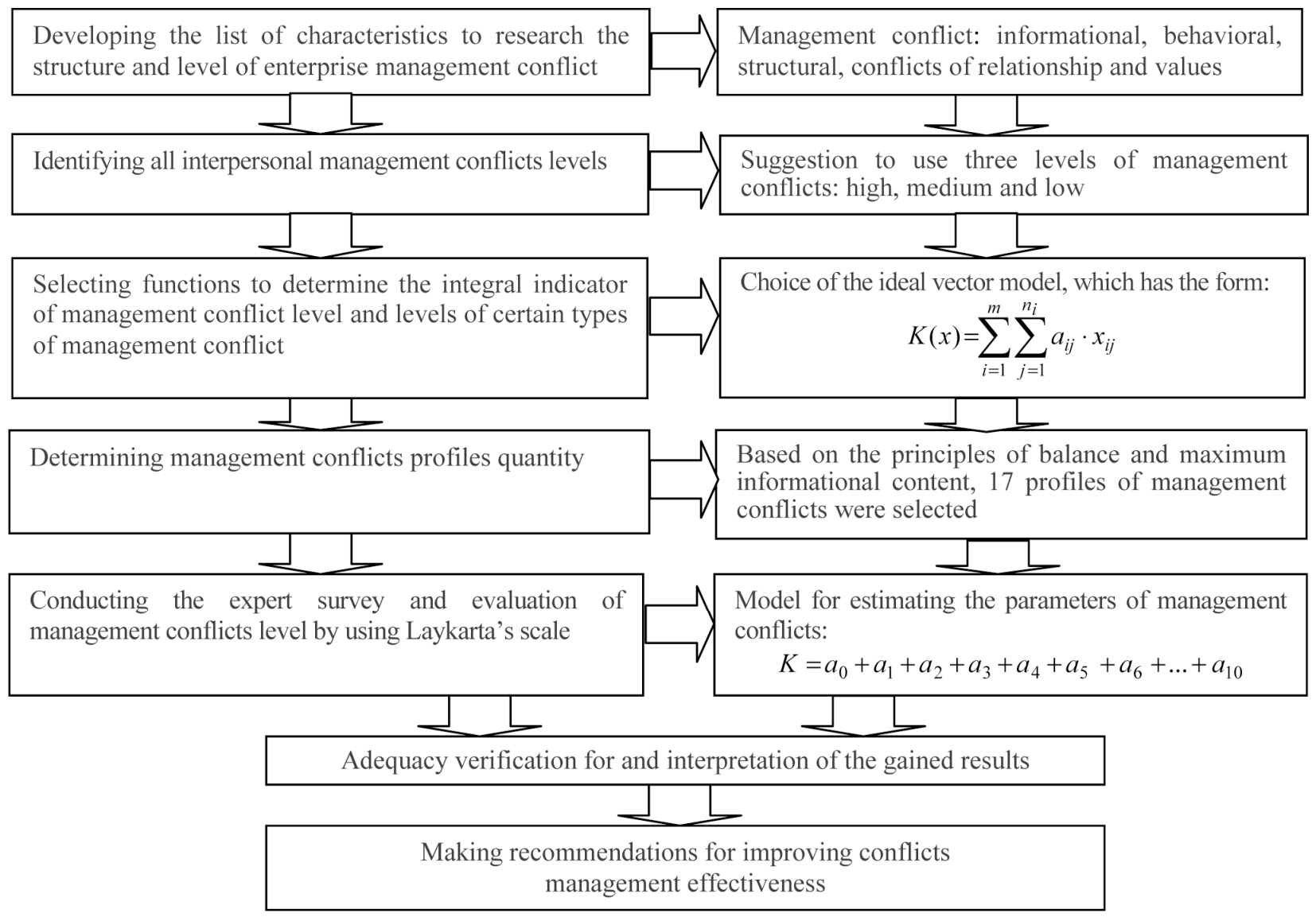

Fig. 1. The sequence of conjoint analysis application to evaluate the level of interpersonal management conflicts

Note: elaborated by authors 


\section{Development methods of conflicts identification and evaluation}

Model for evaluation of the management conflict level and identification of its structure has the form (Malhotra, 2002):

$$
K(x)=\sum_{i=1}^{m} \sum_{j=1}^{n_{i}} a_{i j} \cdot x_{i j},
$$

where $K(x)$ - integral evaluation of management conflict level at the enterprise; $x_{i j}$ - evaluation of certain types of management conflict at the enterprise; $a_{i j}$ - parameter of the independent variable that corresponds to the $j$-th level $\left(j \in \overline{1, n_{i}}\right.$ ), $i$-th type of conflict; $n$ - number of evaluation levels; $m$ - number of management conflicts.

To receive the most adequate and credible results of the management conflict level evaluation all possible profiles combinations should be determined. In practice, however, the amount of all profiles is limited on the basis of detection of correlative connections between the profiles by using orthogonal method. In our research it is reasonable to evaluate 17 profiles that do not correlate with others; to be more specific, the correlation coefficient is minimal between the profiles (Table 1).
Based on the number of selected management conflicts and their levels, the formula for estimating the parameters will have the following form:

$$
K=a_{0}+a_{1} x_{1}+\ldots \ldots .+a_{10} x_{10},
$$

where $K$ - integral management conflict level indicator; $a_{1}-a_{10}-$ variables, different management conflicts of enterprises.

Practically, we create a common multifactorial correlative-regressive model with fictitious variables that take the value of either 0 or 1 . Calculation of equation parameters is carried out by using the method of the least squares, where the respondents evaluation is the dependent variable and formed combinations of management conflict are independent variables.

Therefore the calculated model for the joint venture "Sferos Electron" has the following form:

$$
\begin{gathered}
K_{1}=3,32312+2,03231 x_{1}+0,89795 x_{2}- \\
-0,5493 x_{3}-0,801 x_{4}+0,21768 x_{5}- \\
-0,1496 x_{6}-0,1564 x_{7}-0,3027 x_{8}- \\
-0,3486 x_{9}-0,4132 x_{10} .
\end{gathered}
$$

\begin{tabular}{|c|c|c|c|c|c|c|c|c|c|c|c|}
\hline \multirow{2}{*}{\multicolumn{2}{|c|}{$\begin{array}{l}\text { The average level of conflicts } \\
\text { at the enterprises }\end{array}$}} & \multicolumn{10}{|c|}{ Profiles of interpersonal management conflicts } \\
\hline & & \multicolumn{2}{|c|}{ Informational } & \multicolumn{2}{|c|}{ Behavioral } & \multicolumn{2}{|c|}{ Relationship } & \multicolumn{2}{|c|}{ Values } & \multicolumn{2}{|c|}{ Structural } \\
\hline $\begin{array}{l}\text { JV "Sferos } \\
\text { Elektron" }\end{array}$ & $\begin{array}{c}\text { LLC } \\
\text { "Robitnia" }\end{array}$ & $X_{1}$ & $X_{2}$ & $X_{3}$ & $X_{4}$ & $X_{5}$ & $X_{6}$ & $X_{7}$ & $X_{8}$ & $X_{9}$ & $X_{10}$ \\
\hline 2 & 2,25 & 0 & 0 & 0 & 1 & 0 & 0 & 0 & 1 & 0 & 1 \\
\hline 1,714286 & 2,375 & 0 & 0 & 1 & 0 & 0 & 1 & 0 & 1 & 0 & 1 \\
\hline 2 & 3,375 & 0 & 0 & 0 & 1 & 1 & 0 & 0 & 1 & 0 & 1 \\
\hline 3,142857 & 2,875 & 0 & 1 & 1 & 0 & 0 & 1 & 1 & 0 & 0 & 0 \\
\hline 3,428571 & 2,875 & 0 & 1 & 0 & 1 & 1 & 0 & 1 & 0 & 0 & 0 \\
\hline 2,714286 & 2,875 & 0 & 1 & 1 & 1 & 0 & 0 & 1 & 0 & 0 & 0 \\
\hline 3,714286 & 3,5 & 1 & 0 & 0 & 1 & 1 & 0 & 1 & 0 & 1 & 0 \\
\hline 4,571429 & 2,625 & 1 & 0 & 1 & 0 & 0 & 1 & 1 & 0 & 1 & 0 \\
\hline 3,714286 & 3,5 & 1 & 0 & 0 & 1 & 0 & 0 & 1 & 0 & 1 & 0 \\
\hline 2,571429 & 2,5 & 0 & 0 & 1 & 0 & 1 & 0 & 0 & 1 & 0 & 0 \\
\hline 2 & 2,375 & 0 & 0 & 0 & 1 & 1 & 0 & 0 & 1 & 0 & 1 \\
\hline 3 & 2,625 & 0 & 1 & 1 & 0 & 0 & 1 & 1 & 0 & 0 & 1 \\
\hline 2,714286 & 2,25 & 0 & 1 & 0 & 1 & 0 & 1 & 1 & 0 & 1 & 0 \\
\hline 4,142857 & 3,75 & 1 & 0 & 0 & 1 & 0 & 0 & 0 & 1 & 1 & 0 \\
\hline 4,428571 & 2,75 & 1 & 0 & 1 & 0 & 0 & 0 & 0 & 1 & 0 & 0 \\
\hline 3 & 2,875 & 0 & 0 & 1 & 0 & 1 & 0 & 1 & 0 & 0 & 0 \\
\hline 3,142857 & 2 & 0 & 1 & 1 & 0 & 0 & 0 & 1 & 0 & 1 & 0 \\
\hline
\end{tabular}

\section{An average value of interpersonal management conflicts profiles evaluation at the machine-building enterprises}

Note: generated on the basis of expert surveys 
Furthermore, having considered the input data of LLC "Robitnia", the conjoint analysis models parameters have been calculated for research of the interpersonal management conflicts structure and levels. The formula is the following:

$$
\begin{gathered}
K_{2}=2,48976+1,0536 x_{1}+0,19196 x_{2}- \\
-0,0138 x_{3}+0,42215 x_{4}+0,44828 x_{5}+ \\
+0,07998 x_{6}-0,215 x_{7}-0,3859 x_{8}- \\
-0,389 x_{9}-0,0354 x_{10} .
\end{gathered}
$$

The received regressive models contain only the values of 10 levels of different management conflicts types. Therefore, we should find the values of the other 5 levels of management conflicts and identify the prevailing management conflicts in the structure of conflicts that arise in the machinebuilding enterprises functioning (Table 2).

Having applied the formulae for determining the fixed weight of management conflicts in the overall structure of interpersonal conflict at the machine-building enterprises, we have got the results presented in Table 3 .

In order to interpret management conflict patterns at the machine-building enterprises the appropriate graphs have been formed (Fig. 2 and Fig. 3).

Table 2

Characteristics of interpersonal management conflicts levels and partial weight of these levels

\begin{tabular}{|l|c|c|c|}
\hline \multirow{2}{*}{ Management conflicts } & \multirow{2}{*}{ Levels } & \multicolumn{2}{|c|}{ Partial weights } \\
\cline { 2 - 4 } & & JV “Sferos Elektron" & LLC "Robitnia” \\
\hline Informational conflicts & High & 1,05556 & 0,638464 \\
\cline { 2 - 4 } & Medium & $-0,07879$ & $-0,223236$ \\
\cline { 2 - 4 } & Low & $-0,97676$ & $-0,4152$ \\
\hline \multirow{3}{*}{ Behavioral conflicts } & High & $-0,09914$ & $-0,149958$ \\
\cline { 2 - 4 } & Medium & $-0,35085$ & 0,286056 \\
\cline { 2 - 4 } & Low & 0,45017 & $-0,136098$ \\
\cline { 2 - 4 } Relationship conflicts & High & 0,195012 & 0,27219 \\
\cline { 2 - 4 } & Medium & $-0,172335$ & $-0,096105$ \\
\hline Values conflicts & Low & $-0,022675$ & $-0,17609$ \\
\cline { 2 - 4 } & High & $-0,0034$ & $-0,0147$ \\
\cline { 2 - 4 } & Medium & $-0,14964$ & 0,18563 \\
\hline Structural conflicts & Low & 0,15306 & $-0,24755$ \\
\cline { 2 - 4 } & High & $-0,09467$ & 0,10605 \\
\cline { 2 - 4 } & Medium & $-0,1593$ & 0,14149 \\
\hline
\end{tabular}

Note: calculated by authors

Table 3

Results of the fixed weight of management conflicts

\begin{tabular}{|l|c|c|c|c|}
\hline \multicolumn{1}{|c|}{$\begin{array}{c}\text { Management } \\
\text { conflicts }\end{array}$} & \multicolumn{2}{|c|}{ Relative fixed weights of management conflicts } & \multicolumn{2}{c|}{ Interpretation of received results } \\
\cline { 2 - 5 } $\begin{array}{l}\text { Informational } \\
\text { conflicts }\end{array}$ & 1 & 1 & $\begin{array}{c}\text { The most significant } \\
\text { conflict }\end{array}$ & $\begin{array}{c}\text { The most significant } \\
\text { conflict }\end{array}$ \\
\hline $\begin{array}{l}\text { Behavioral } \\
\text { conflicts }\end{array}$ & 0,28811 & 0,074964 & $\begin{array}{c}\text { The second place in terms } \\
\text { of conflict significance }\end{array}$ & $\begin{array}{c}\text { The third place in terms } \\
\text { of conflict significance }\end{array}$ \\
\hline $\begin{array}{l}\text { Relationship } \\
\text { conflicts }\end{array}$ & 0,184899 & 0,093335 & $\begin{array}{c}\text { The third place in terms of } \\
\text { conflict significance }\end{array}$ & $\begin{array}{c}\text { The second place in } \\
\text { terms of conflict } \\
\text { significance }\end{array}$ \\
\hline $\begin{array}{l}\text { Values conflicts } \\
\text { Structural conflicts }\end{array}$ & 0,063927 & 0 & $\begin{array}{c}\text { The least significant } \\
\text { conflict }\end{array}$ & $\begin{array}{c}\text { The least significant } \\
\text { conflict }\end{array}$ \\
\hline
\end{tabular}

Note: calculated by authors on the basis of conjoint analysis 
Development methods of conflicts identification and evaluation
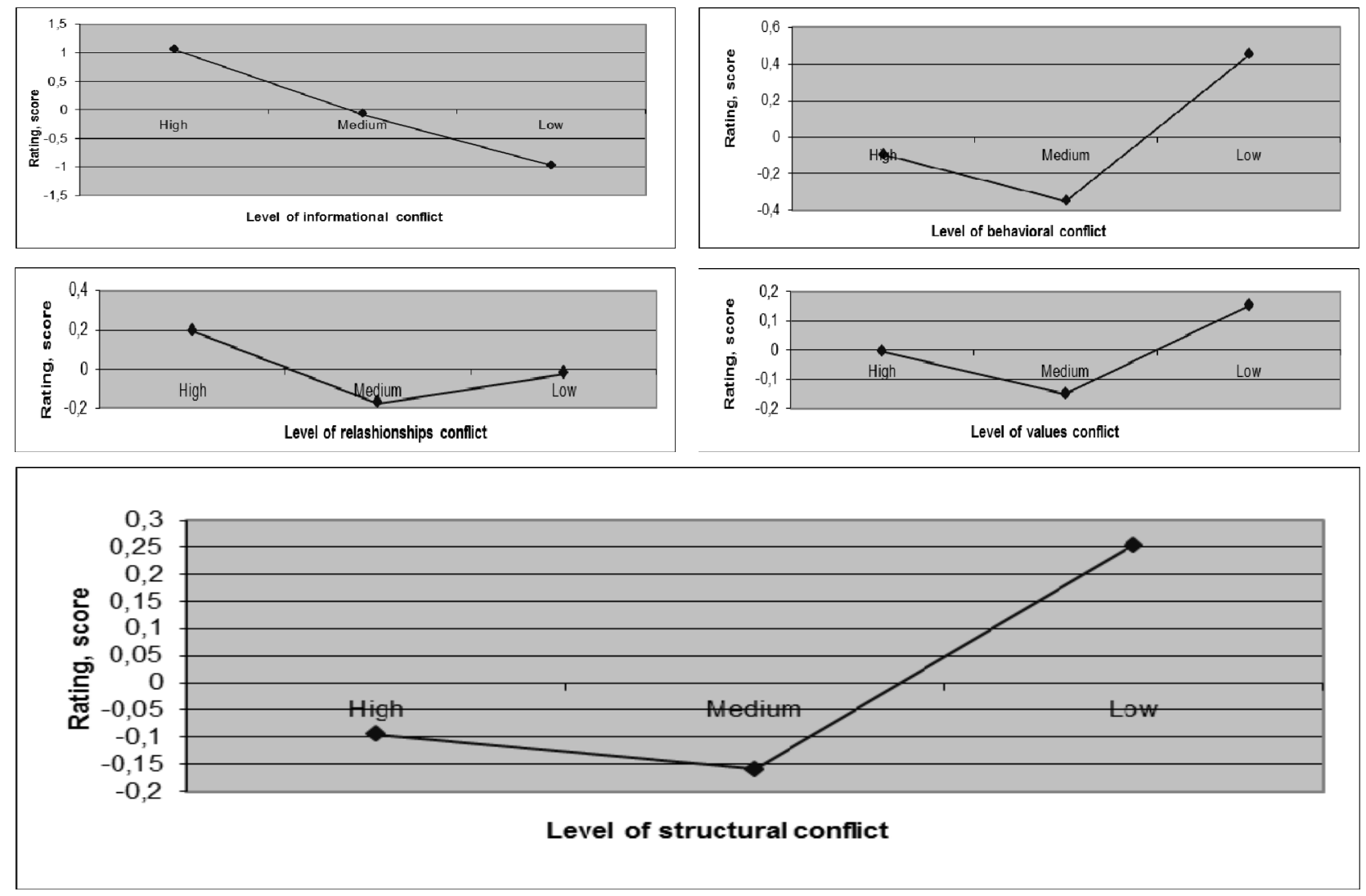

Fig. 2. The structure and level of management conflicts in the functioning of JV "Sferos Electron" Note: elaborated by authors using the conjoint analysis method
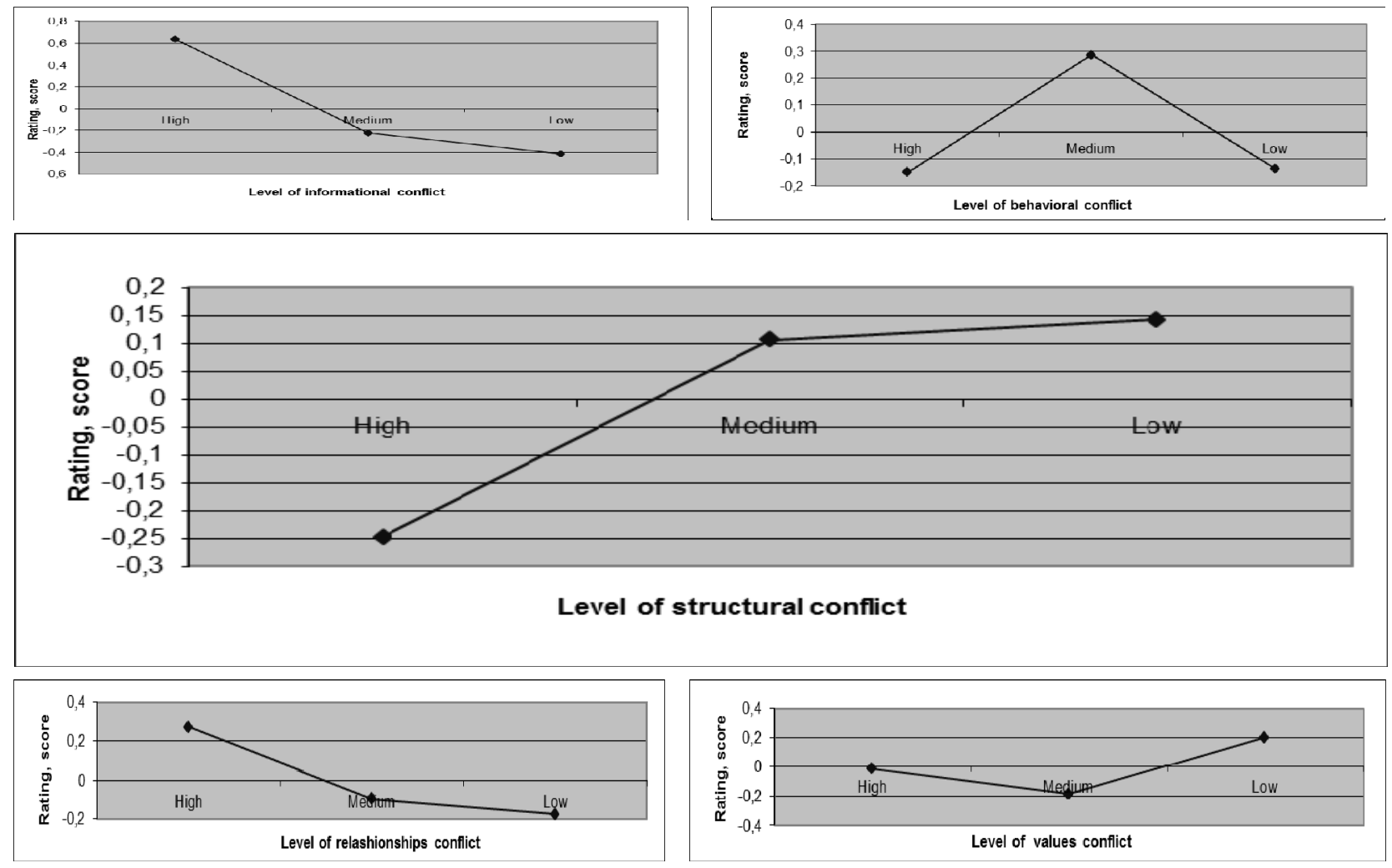

Fig. 3. The structure and level of management conflicts in the functioning of LLC "Robitnia" Note: elaborated by authors 


\section{N. Y. Podolchak, G. R. Kovalchuk, O. I. Savchyn}

Conclusions and prospects for further research. The structure of management conflicts in the functioning of machine-building companies is quite similar. The research has made it possible to detect that in the structure of management conflict the dominant ones are informational conflicts that are related to poor information support from the companies' administrators. Hereby the level of informational conflicts is rather significant. Experts draw attention especially to the unsatisfactory level of information support of management decisionmaking process, lack of information about changes in the environment, asymmetry of information in the various stakeholder groups. Therefore, the main recommendation for elimination of the conflict's dysfunctional consequences for the company is the necessity to direct resources at the improvement of communication channels and to take measures regarding the management decision-making process information support development.

For the functioning of the JV "Sferos Electron" behavioral management conflicts are rather essential. The main reasons for their occurrence at the investigated enterprise are dominance of private arrangements, nepotism, active influence of informal organizations that sometimes can prevail over rationality and efficiency in management decisionmaking. The settlement of such conflicts is possible by implementing definite standards of behavior and decision-making process and absolute adherence to those standards.

For the LLC "Robitnia" the second place in terms of significance in the structure of the enterprise management conflict is taken by relationships conflicts that display a high level of dynamism and, thus, bring turbulence and uncertainty into the activities of administrative management subsystem. According to the experts, the reason for the appearance and dominance of behavioral conflicts in the enterprises functioning is the lack of power balance in the relationships between the leaders.

As for the JV "Sferos Electron", the management conflict of relationships takes only the third place in terms of significance. Interestingly, the level of relationships conflict is as high as for the previous enterprise. Consequently, both companies should take measures to improve the relationships between managers by developing corporate unity programs.

In the third place in terms of dominance in the structure of general management conflict at the
"Robitnia" enterprise there are behavioral conflicts, while structural conflicts take the penultimate place. In addition, it was discovered that the level of all structural conflicts that occur in both mentioned above companies is quite low. Thus, the objective circumstances of conflicts appearance that cannot be changed are not significant in terms of conflicts occurrence. In the structure of the management conflict in the functioning of both companies the least important one is the conflict of values.

Further research should be focused on developing result-based methods that would help to reduce and avoid interpersonal management conflicts in the machine-building enterprises functioning.

\section{References}

1. Горностай П. П. Вимірювання параметрів рольового конфлікту: зарубіжний досвід / П. П. Горностай // Конфліктологічна експертиза: теорія та методика. - Bип. 1. - К., 1997. - C. 116-125.

2. Ерина С. И. Диагностика ролевого конфликта в деятельности руководителя / С. И. Ерина, Н. П. Фетискин, В. В. Козлов, Г. М. Мануйлов. Сочиально-психологическая диагностика развития личности и мальх групп. - М., 2002. - 320 с.

3. Аниупов А. Я. Конфликтология в схемах и комментария / А. Я. Аниупов, С.В. Баклановский. 2-е изд., перераб. - СПб. : Питер, 2009. - 304 с.

4. Корнелиус Х. Выиграть может каждый. Как разрешать конфликты / Х. Корнелиус, Ш. Фэйр. М. : Стрингер, 1992. - 386 c.

5. Малхотра Н. Маркетинговые исследования / Н. К. Малхотра. - 3-е изд. ; пер. с англ. - М. : 2002. $-960 \mathrm{c}$.

6. Полозова T. А. (2007) Диагностика Межличностных конфликтов в группе [електрон. ресурс]. / Т. А. Полозова. - Режим доступу: http://www.gurutestov.ru/category/6/

7. Рябиев В. Н. Конфликтология : хрестоматия / В. Н. Рябиев, М. А. Шитив. - Ростов-на-Дону, 2001. $-488 \mathrm{c}$.

8. Сівчук I. Методичні аспекти оиінювання конфліктів на підприємстві у контексті корпоративної культури / I. Сівчук // Галицький економічний вісник. - 2012. - № 6(39). - C. 65-70.

9. Цюрупа М. В. Основи конфліктології та теорії переговорів / М. В. Цюрупа. - К., 2004. - 172 c.

10. Bem S. L. The measurement of psychological / S. L. Bem // Journal of Consulting and Clinical Psychology. - 1974. - P. 115-162.

11. Smith C. S. The measurement properties of the role conflict and role ambiguity scales: A review and extension of the empirical research / C. S. Smith // Journal of Organizational Behavior. - 1993. Vol. 14(1). - P. 37-48. 